\title{
Multichromophoric sensitizers based on calix[4]arene scaffold and 4H-pyranylidene moiety for DSSCs application
}

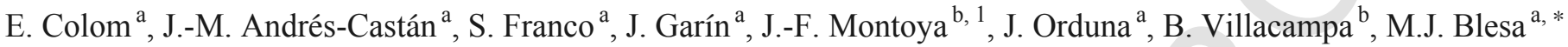 \\ a Departamento de Química Orgánica-ICMA, Universidad de Zaragoza-CSIC, 50009, Zaragoza, Spain \\ ${ }^{\mathrm{b}}$ Departamento de Física de la Materia Condensada-ICMA, Universidad de Zaragoza-CSIC, 50009, Zaragoza, Spain
}

\section{A R T I C L E I N F O}

Article history:

Received 1 August 2016

Received in revised form 29 August

2016

Accepted 31 August 2016

Available online xxx

Keywords:

DSSC

Metal-free sensitizer

Multichromophore

Calix[4]arene

$4 H$-pyranylidene

Aggregation

\section{Introduction}

Lasts years, Grätzel solar cells, or Dye Sensitized Solar Cells (DSSCs), have gained importance. These cells consist in an inorganic semiconductor sensitized by a dye. Most of organic sensitizers have a typical electron Donor- $\pi$-Acceptor structure (D- $\pi$-A) [1-3]. Recently, this kind of metal-free organic dyes have been

\section{* Corresponding author}

Email addresses: ecolomsienes@gmail.com (E. Colom); chemandres.oboist@ gmail.com (J.-JM. -M Andrés-Castán); sfranco@unizar.es (S. Franco); jgarin@ unizar.es (J. Garín); jfmonto0@gmail.com (J.-JF.-F Montoya); jorduna@unizar. es (J. Orduna); bvillaca@unizar.es (B. Villacampa); mjblesa@unizar.es (M.J. Blesa)

${ }^{1}$ Current address: Departamento de Ciencias Básicas, Corporación Universitaria Lasallista, 055448 Caldas, Antioquia, Colombia. paid more attention because of their flexibility, tunable structural arrangement with an intramolecular charge transfer (ICT) absorption band, high molar extinction coefficient in the visible region of the sun spectrum, and environmental friendliness [4-9]. The efficiencies of organic dyes have been improving continuously and values up to $12.8 \%$ have already been achieved [10].

Triarylamines moieties are commonly used as electron donors because of their excellent electron-donating capability and good stability $[11,12]$. $4 H$-pyranylidene ring has proved to be a very good donor system in nonlinear optical (NLO) applications [13] but it has scarcely been explored in DSSCs [14]. Its main feature relies on its proaromatic caracter that improves the charge transfer process through the gain in aromaticity. Moreover, the electronic properties can be modulated by incorporating substituents with different electronic behaviour [15-18].

The $\pi$-bridge plays an important role in tuning the main photochemical properties [19-23] of the sensitizer and it is commonly used with the aim to expand the solar cell absorption spectrum to the red region of the sun light. The use of thiophene-based $\pi$-bridge also affords chemical stability to the final dye.

Most of the D- $\pi$-A organic dyes utilize the cyanoacrylic acid anchoring moiety because of the presence 
of an electron withdrawing cyano group near the anchoring carboxylic acid group that enhances the spectral response through intramolecular charge transfer (ICT) and its good electron injection properties [23-27].

When designing a new sensitizer, one important factor to take into account is related to the reduction of aggregates formation by $\pi$ - $\pi$-stacking. This may be performed by using additives, such as deoxycholic acid $[28,29]$ or by the introduction of bulky groups either in the donor part of the molecule or in the bridge [15].

Moreover, last studies on DSSC have shown that the presence of several anchoring groups in one molecule improves the photovoltaic properties [30-32]. Our research group has used the calix[4]arene scaffold to preorganize several chromophores in one single molecule with far away enough to behave as independient chromophores and so providing several light-harvesting units per molecule which favors high molar extinction coefficients [33,34]. Moreover, the $p$-tert-butyl substituted calix[4] arene derivative has bulky alkyl chains, which increase the solubility of the systems and it is expected to impede dye aggregation. In addition, these systems can be immobilized in cone conformation by the introducing of propyl or longer groups into the lower rim $[35,36]$. Despite the fact that calix[4]arene derivatives possess so many applications [37], the investigation of calix[4]arene-based sensitizers as a key component in DSSCs has been scarcely reported. One paper is published with calix[4] arene as donor unit [38], and just one has been published by our research group using the calixarene as scaffold to orient the anchoring groups with one type of dye [34]. This paper shows noticeable achievements such as the increase of the $V_{o c}$, the slow aggregates formation and the improvement on the solubility [34].

Therefore, we prepare for the first time systems for DSSCs consisting of two different dyes based on a tert-butyl-substituted calix[4]arene used as scaffold, a triphenylamine or a $4 H$-pyranylidene donor, a 2-cyanoacrylic acid acceptor, and a thiophene spacer pursuing to expand the solar cell absorption spectrum with respect to the reported calixarene based on triphenylamine [34]. This system will be compared with the calixarene derivative prepared with two equal chromophores, based on $4 H$-pyranylidene as a donor with the aim to obtain a deeper insight into the structure-properties relationship of these dyes.

\section{Results and discussion}

\subsection{Synthesis and characterization}

The structures of dyes (TPA), (P), (Cx-2-TPA), (Cx-2-P) and (Cx-P-TPA) are depicted in Scheme 1.

The dye (P) has been previously synthetised in our research group with good photovoltaic performance [17] and is used in order to compare the photovoltaic properties of the devices prepared with

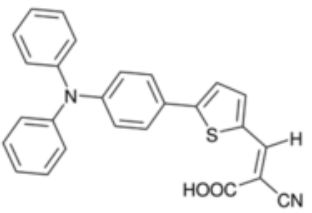

(TPA)

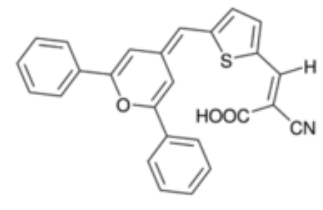

(P)
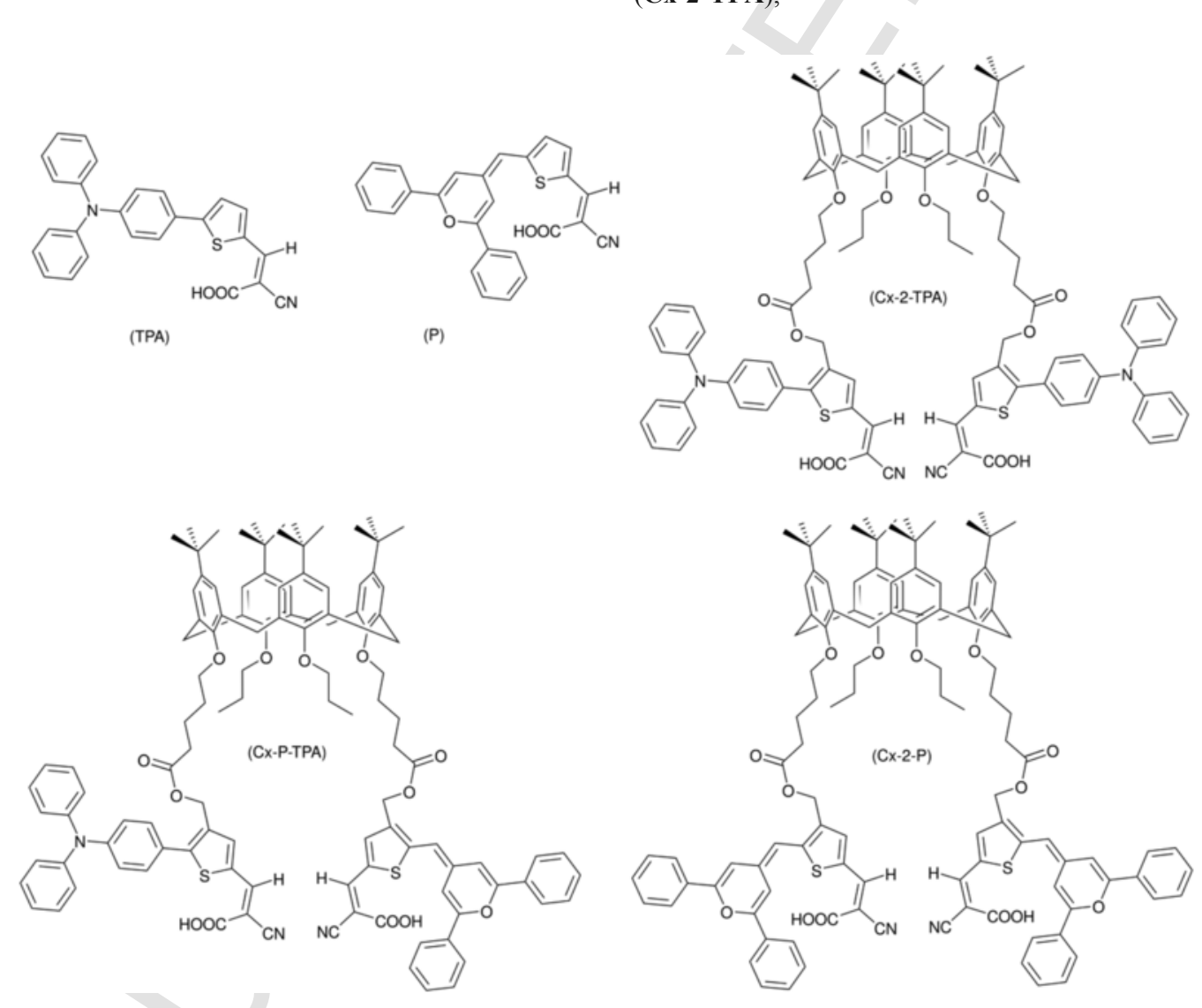

Scheme 1 . 
(Cx-P-TPA) and (Cx-2-P) dyes. These calixarene derivatives are synthesized according with the detailed synthesis reported below.

Scheme 2 shows the preparation of compounds (1) and (2). The synthesis of compound (1) was already described in a previous paper [34]. Analogously, the tert-butyldimethylsilyl group of the compound (P-2) was removed with tetrabutylammonium fluoride in anhydrous tetrahydrofuran at room temperature to give compound (2).

The esterification of the hydroxyl group of compounds (1) and (2) with the corresponding carboxylic acid derivative of calixarene $(\mathbf{C x}-2)$, prepared as described in the literature [39-42], was carried out by a Steglich reaction using 1-ethyl-3-(3-dimethylaminopropyl)carbodiimide (EDC). Scheme 3 shows the obtained aldehydes (3), (4) and (5). Finally, the desired dyes (Cx-2-TPA), (Cx-P-TPA), (Cx-2-P) were obtained by Knoevenagel reaction of the aforementioned aldehydes (3), (4) and (5) with cyanoacetic acid in the presence of piperidine (Scheme 3). All intermediates and final organic dyes have been completely characterised.

\subsection{Optical properties}

The optical properties were studied by UV-vis spectroscopy by measuring dye solutions $10^{-5} \mathrm{M}$ in $\mathrm{CH}_{2} \mathrm{Cl}_{2}$. The absorption spectra of the dyes (P), (Cx-2-TPA), (Cx-P-TPA) and (Cx-2-P) are shown in Supporting Information (Fig. S.1-S.5). Inspection of spectra reveals that the compound (Cx-2-TPA) shows a band in the visible region from $370 \mathrm{~nm}$ to $550 \mathrm{~nm}$ which is attributed to a strong intramolecular charge transfer transition (ICT) between TPA-donor and cyanoacetic acid-acceptor. Compounds (P) and (Cx-2-P) exhibit a strong and broad band ranging from 450 to $650 \mathrm{~nm}$ that can be also assigned to an ICT process between $4 H$-pyranylidene-donor and cyanoacetic acid-acceptor. The calixarene derivative (Cx-P-TPA), which is constituted by both (TPA) and (P) dyes, shows a broad absorption band in the visible region from $370 \mathrm{~nm}$ to $650 \mathrm{~nm}$ which is attributed to the two strong intramolecular charge transfer transition (ICT) between donor and acceptor due to the presence of the two moieties (TPA) and $(\mathbf{P})$ in calixarene (Cx-P-TPA). The molar extinction coefficient $(\varepsilon)$ of these compounds have been also established. Table 1 shows that these dyes have $\varepsilon$ ranging from 10800 to $43500 \mathrm{M}^{-1} \mathrm{~cm}^{-1}$ and it is noticeable the increase of this value for the (Cx-2-TPA) and (Cx-2-P) systems with respect to (TPA) and (P), respectively. However, the $\varepsilon$ of $(\mathbf{C x}-\mathbf{2}-\mathbf{P})$ is lower than expected which could be explained by interchromophore interactions. As $\varepsilon$ values are directly related to the amount of radiation which is absorbed by the molecule at a given wavelength, calixarene derivatives with two (TPA) or (P) chromophores in the same scaffold could have potential application in low-luminosity conditions.

When dyes (Cx-2-TPA) and (Cx-2-P) are attached to $\mathrm{TiO}_{2}$ surface, the maximum absorption peaks are blue shifted as compared to those in solution (Fig. 1a and b). In general, the blue shifts of the absorption spectra on $\mathrm{TiO}_{2}$ could be ascribed to deprotonation of the dyes and/or formation of $H$-aggregates (extended head to tail stacking) [43] of the dyes on the $\mathrm{TiO}_{2}$ surface. The UV-vis spectra of films taken after different time intervals of immersion show evidence of aggregation after $4 \mathrm{~h}$ of immersion in devices prepared with<smiles>CC(C)(C)[Si](C)(C)OCc1cc(C=O)sc1-c1ccc(N(c2ccccc2)c2ccccc2)cc1</smiles>

(P-1)<smiles>CC(C)(C)[Si](C)(C)OCc1cc(C=O)sc1C=C1C=C(c2ccccc2)OC(c2ccccc2)=C1</smiles>

(P-2)

\section{TBAF/THF}

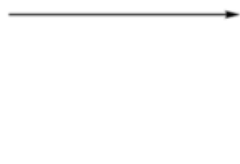

TBAF/THF
(1)<smiles>O=Cc1cc(CO)c(-c2ccc(N(c3ccccc3)c3ccccc3)cc2)s1</smiles><smiles>O=Cc1cc(CO)c(C=C2C=C(c3ccccc3)OC(c3ccccc3)=C2)s1</smiles>

(2)

Scheme 2 .

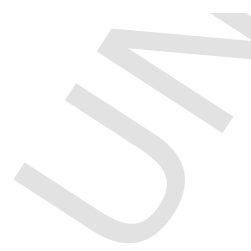




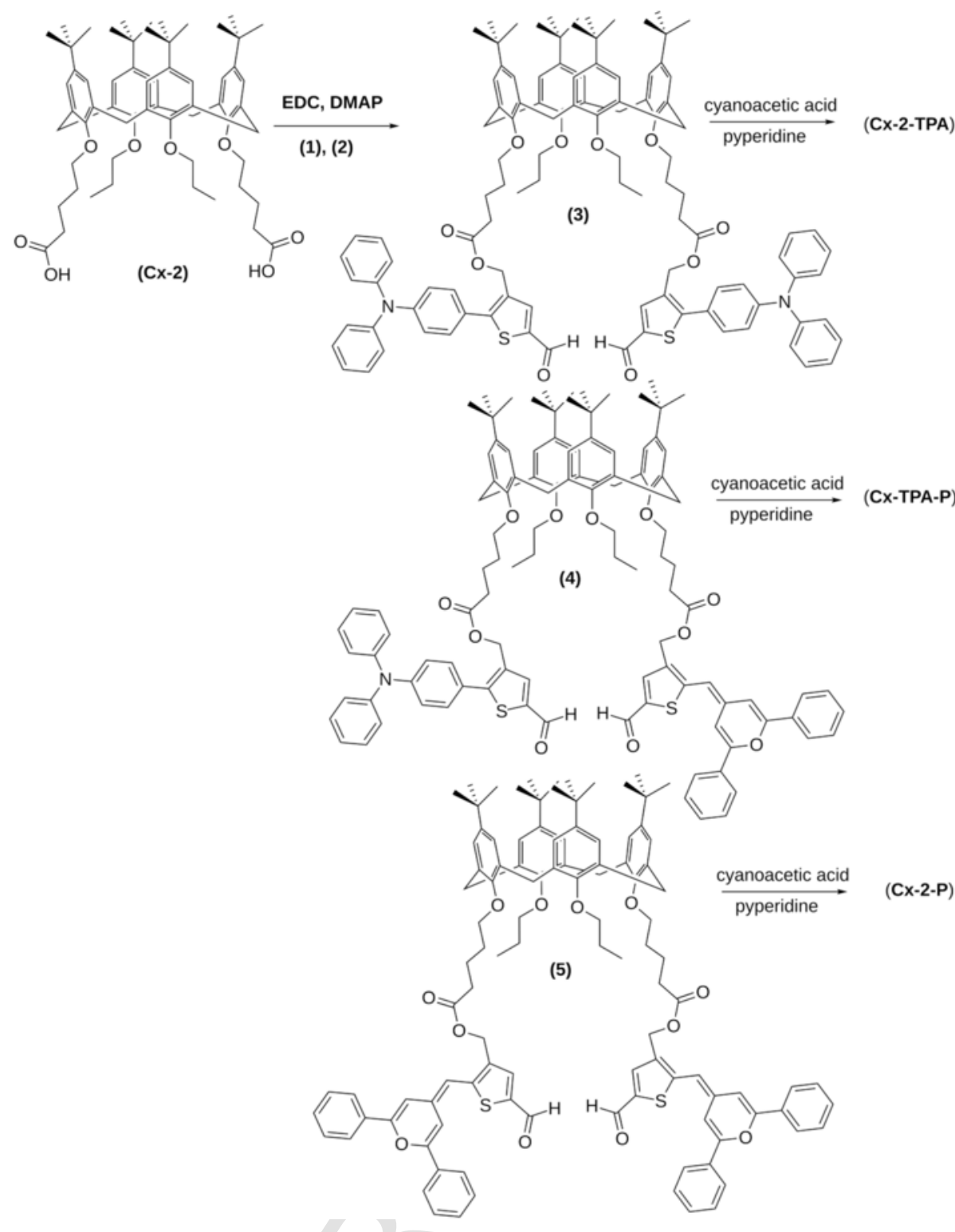

Scheme 3.

(Cx-2-TPA) (Fig. 2a). However, in this work no aggregation is observed when the dye (Cx-2-P) is soaked for $24 \mathrm{~h}$ (Fig. 2b).

\subsection{Electrochemical properties}

The electrochemical properties of the dyes (TPA), (P), (Cx-2-TPA), (Cx-2-P) and (Cx-P-TPA) were studied by Differential Pulse Voltammetry (DPV). Voltammograms were performed in $\mathrm{CH}_{2} \mathrm{Cl}_{2}$ using $0,1 \mathrm{M}$ tetrabutylammonium hexafluorophosphate as supporting electrolyte, a glassy carbon as working electrode, a Pt as counter electrode and a $\mathrm{Ag} / \mathrm{AgCl}$ as reference electrode. The solution of the dyes was $10^{-4} \mathrm{M}$ in $\mathrm{CH}_{2} \mathrm{Cl}_{2}$. The electrochemical data of these dyes are also listed in Table 1 which shows the oxidation potential of both ground and excited states of these dyes. The oxidation potential of the ground state, $E_{o x}$, is below the electrolyte potential (the redox potential $\mathrm{I}^{-} / \mathrm{I}_{3}{ }^{-}$has a value of $+0.4 \mathrm{~V}$ ) which is necessary to ensure that neutral dye is effectively regenerated after being oxidized [44] and the oxidation potential of the excited state, $E_{o x}{ }^{*}$, is above the $\mathrm{TiO}_{2}$ potential $(-0,5 \mathrm{~V}$ vs NHE) in favour of efficient electron injection from the excited dye onto the $\mathrm{TiO}_{2}$ electrode.

In order to establish a comparison we have included the parameters of the previous reported dyes (TPA) and (Cx-2-TPA) [34]. The oxidation potential values of dyes (TPA) and (Cx-2-TPA), are similar, $+1.17 \mathrm{~V}$ and $+1.24 \mathrm{~V}$ because it corresponds to the oxidation of the TPA-donor moiety and the values of the dyes (P), (Cx-2-P) and (Cx-P-TPA) are also similar, $+0.81 \mathrm{~V},+0.75 \mathrm{~V}$ and $+0.79 \mathrm{~V}$, respectively; which are attributed to the oxidation of the $4 H$-pyranylidene-donor 
Table 1

Linear optical and electrochemical properties of the dyes (TPA), (Cx-2-TPA), (P), (Cx-2-P), (Cx-P-TPA).

\begin{tabular}{|c|c|c|c|c|c|c|c|}
\hline Dye & $\lambda_{\mathrm{abs}}{ }^{\mathrm{a}}(\mathrm{nm})$ & $\lambda_{\mathrm{abs}}^{\mathrm{b}}(\mathrm{nm})$ & $\varepsilon \times 10^{-4}\left(\mathrm{M}^{-1} \mathrm{~cm}^{-1}\right)$ & $\log \varepsilon$ & $E_{0-0}^{\mathrm{c}}(\mathrm{eV})$ & $E_{o x}{ }^{\mathrm{d}}(\mathrm{V})$ & $E_{o x}^{*}{ }_{o x}^{\mathrm{c}, \mathrm{d}}(\mathrm{V})$ \\
\hline TPA & 437 & 416 & $1.08 \pm 0.02$ & 4.03 & 2.40 & +1.17 & -1.23 \\
\hline Cx-2-TPA & 451 & 418 & $2.81 \pm 0.03$ & 4.45 & 2.36 & +1.24 & -1.12 \\
\hline $\mathbf{P}$ & 556 & 456 & $3.55 \pm 0.30$ & 4.55 & 2.00 & +0.81 & -1.19 \\
\hline Cx-2-P & 557 & 504 & $4.35 \pm 0.02$ & 4.64 & 1.80 & +0.75 & -1.05 \\
\hline \multirow[t]{2}{*}{ CX-P-TPA } & 434 & 433 & $1.51 \pm 0.03$ & 4.18 & 1.85 & +0.79 & -1.06 \\
\hline & 533 & 532 & $1.43 \pm 0.06$ & 4.15 & & & \\
\hline
\end{tabular}

${ }^{\mathrm{e}}$ The estimated oxidation potential of excited state of the dye was calculated from $E_{o x}^{*}=E_{o x}-E_{0-0}$.

a Absorption in $\mathrm{CH}_{2} \mathrm{Cl}_{2}$ solution.

b Absorption on $\mathrm{TiO}_{2}$ films.

${ }^{c} E_{0-0}$ was estimated from the absorption spectra.

d The oxidation potentials were converted to Normal Hydrogen Electrode (NHE) by addition of 0.199 V.
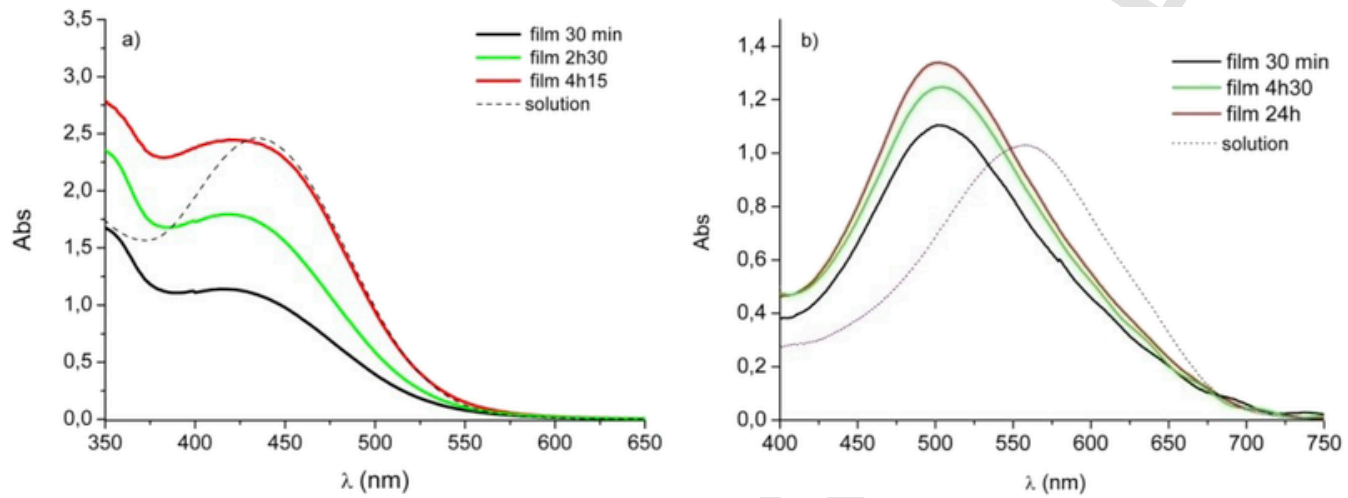

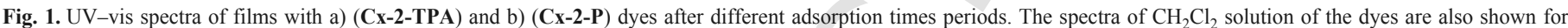
comparision.
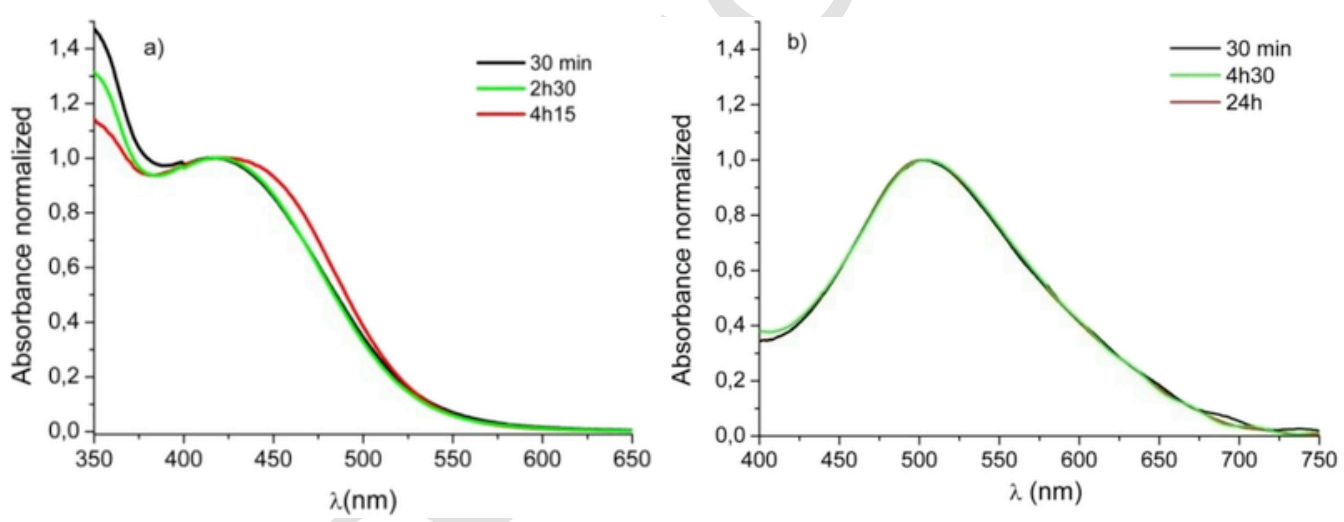

Fig. 2. Normalized UV-vis spectra of films with a) (Cx-2-TPA) and b) (Cx-2-P) dyes after different adsorption times periods.

moiety. Therefore, it can be said that all of them have adequate potentials to be used as dyes for DSSCs.

\subsection{Theoretical calculations}

The electronic structure of dyes (TPA) and (P) has been calculated by means of Density Functional Theory
(DFT) calculations. (Ac-TPA) and (Ac-P) derivatives (Fig. 3), having an acetoxymethyl substituent on the thiophene ring, have been studied as a simplified model for the substituted dyes herein synthesized.

According to these calculations, the lowest energy absorption band is associated to an intramolecular charge transfer (ICT) transition which

is mainly 
Dyes and Pigments xxx (2016) xxx-xxx

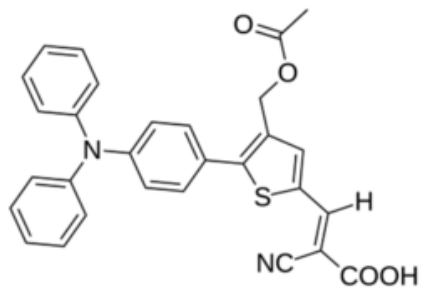

(Ac-TPA)

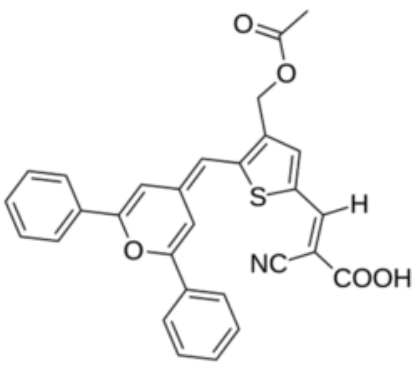

(Ac-P)
Fig. 3. Acetate dyes (Ac-TPA) and (Ac-P) used for DFT calculations.

tributed from a one-electron-HOMO-to-LUMO transition with the HOMO mainly located on the donor group and the LUMO on the cyanoacetic acid acceptor (see Fig. 4).

The calculated energetic parameters related to the photovoltaic properties of these dyes are gathered in Table 2 and it can be seen that there is a reasonably good agreement between calculated and experimental results shown in Table 1. Comparison of (Ac-P) to (P) and (Ac-TPA) to (TPA) reveals that substitution at the thiophene ring has only a minor influence on the elec- tronic structure and therefore it can be seen as a good strategy to avoid intermolecular interactions without modifying the molecular optical and electrical properties.

The comparison of the effect of the donor group reveals that the stronger $4 \mathrm{H}$-pyranylidene donor causes, as expected, higher HOMO energies compared the triphenylamino donor and the calculations also show that these increased HOMO energies are also accompanied by lower LUMO energies. Consequently $4 H$-pyranylidene derivatives display a reduced HOMO-LUMO gap, higher absorption wavelengths, and lower $\mathrm{E}_{0-0}, \mathrm{E}_{\mathrm{ox}}$ and $\mathrm{E}_{\mathrm{ox}}^{*}$ when compared to their triphenylamino analogues.

Besides the electronic structure, the choice of the donor has also an important impact on molecular geometries. Thus, while the cyanoacetic acid acceptor and the thiophene ring are coplanar in all the studied compounds and the pyranylidene ring in (P) and (Ac-P) is only rotated by $8^{\circ}$ with respect to that plane, the phenyl group linked to the thiophene heterocycle in (TPA) is rotated by $23^{\circ}$ and this dihedral angle increases to $39^{\circ}$ due to the steric hindrance caused by the substituent in (Ac-TPA). The external phenyl rings are also rotated with respect to the phenyl ring linked to thiophene by $64^{\circ}$ for both (TPA) and (Ac-TPA) and, in

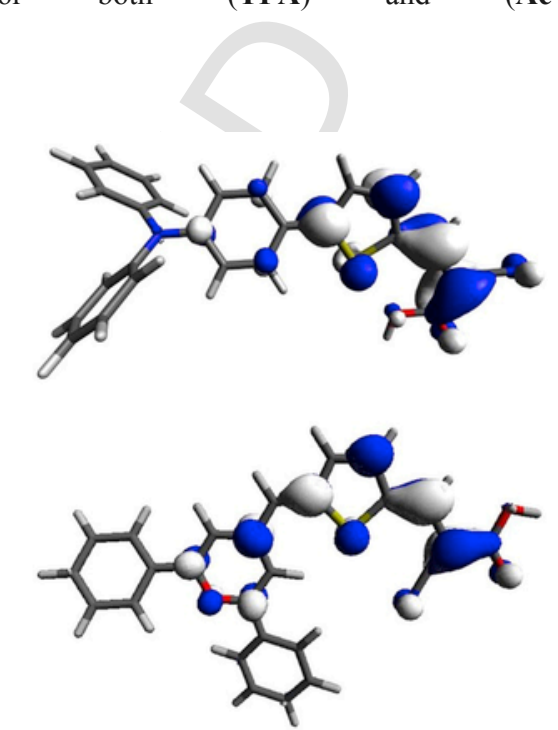

Fig. 4. Molecular orbital contour plots for the HOMO (left) and LUMO (right) of dyes (TPA) and (P).

Table 2

Calculated optical and electrical properties of studied dyes at the CPCM-M06-2x/6-311 + G(2d,p)//CPCM-M06-2x/6-31G(d) level

\begin{tabular}{|c|c|c|c|c|c|c|}
\hline Dye & $\mathrm{E}_{\text {Hомо }}(\mathrm{eV})$ & $\mathrm{E}_{\mathrm{LUMO}}(\mathrm{eV})$ & $\lambda_{\mathrm{abs}}^{\mathrm{a}}(\mathrm{nm})$ & $\mathrm{E}_{0-0}{ }^{\mathrm{b}}(\mathrm{eV})$ & $\mathrm{E}_{\mathrm{ox}}^{\mathrm{c}}(\mathrm{V})$ & $\mathrm{E}_{\mathrm{ox}}^{* \mathrm{c}, \mathrm{d}}(\mathrm{V})$ \\
\hline (TPA) & -6.58 & -2.16 & $430(444)$ & 2.45 & 1.27 & -1.18 \\
\hline (Ac-TPA) & -6.64 & -2.14 & $410(423)$ & 2.52 & 1.32 & -1.21 \\
\hline (P) & -6.43 & -2.30 & $518(550)$ & 2.07 & 0.99 & -1.08 \\
\hline (Ac-P) & -6.46 & -2.35 & $523(556)$ & 2.06 & 1.03 & -1.02 \\
\hline
\end{tabular}

${ }^{\text {a }}$ Non equilibrium solvation calculations with equilibrium CPCM solvation values in parenthesis.

b Approached to adiabatic excitation energy.

c Referenced to Normal Hydrogen Electrode (NHE)

d The oxidation potential of excited state of the dye was calculated from $E_{o x}^{*}=E_{o x}-E_{0-0}$. 
a similar way, the phenyl rings in $(\mathbf{P})$ and $(\mathbf{A c}-\mathbf{P})$ are rotated out of the pyranylidene plane by c.a. $20^{\circ}$. To sum up, (P) and (Ac-P) are more planar than (TPA) and (Ac-TPA) and, therefore, (P) and (Ac-P) are more likely to undergo interchromophore interactions and this is reflected on the relatively low value of the molar extinction coefficient of (Cx-2-P).

It is also noteworthy that triphenylamino dyes undergo significant geometry changes on excitation and thus, the inner phenyl ring that was rotated with respect to thiophene in the ground state becomes coplanar to it in the first excited state of (TPA). This fact can be easily explained on the basis of the higher contribution of the zwitterionic resonance structure to the excited state (Fig. 5). The cartesian coordinates of all the calculated molecular geometries are included as supplementary material.

\subsection{Photovoltaic properties}

The photovoltaic measurements of the sensitizers were studied. Based in our experience with organic dyes, the starting conditions were defined as $0.1 \mathrm{mM}$ for dye and an electrolyte based on the classical I ${ }^{-} / \mathrm{I}_{3}{ }^{-}$system (1-butyl-3-methylimidazolium iodide $(0.53 \mathrm{M})$, LiI $(0.10 \mathrm{M}), \mathrm{I}_{2}(0.050 \mathrm{M})$ and tert-butylpyridine $(0.52 \mathrm{M})$ in anhydrous acetonitrile).

Firstly, the devices with calixarene dyes (Cx-2-TPA), (Cx-2-P) and (Cx-P-TPA) were prepared after $5 \mathrm{~h}$ of immersion of the electrode in dye solutions according to previous studies carried out in our research group [14]. The results obtained upon the photovoltaic characteri-
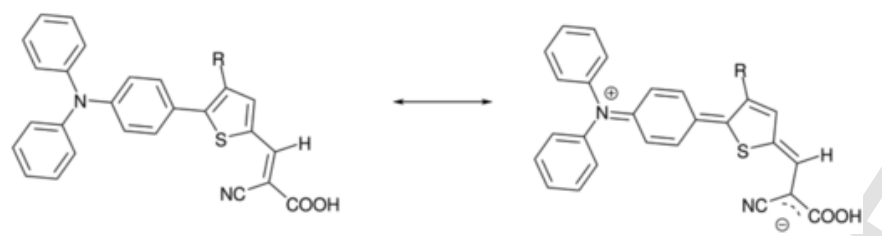

Table 3

Photovoltaic performance parameters of DSSCs based on adsorbed calixarenes under AM $1.5 \mathrm{G}$ simulated solar light $\left(100 \mathrm{~mW} \mathrm{~cm}^{-2}\right)$ and $5 \mathrm{~h}$ of electrode immersion on dyes.

\begin{tabular}{llllll}
\hline Dye & Additive & $V_{o c}(\mathrm{mV})$ & $J_{s c}\left(\mathrm{~mA} / \mathrm{cm}^{2}\right)$ & $f f(\%)$ & $\eta(\%)$ \\
\hline Cx-2-TPA & - & 752 & 8.56 & 56.96 & 3.67 \\
CX-2-TPA & CDCA & 732 & 7.82 & 62.11 & 3.56 \\
Cx-2-P & - & 604 & 12.75 & 59.73 & 4.61 \\
Cx-2-P & CDCA & 597 & 9.97 & 65.33 & 3.89 \\
Cx-P-TPA & - & 616 & 10.43 & 60.99 & 3.92 \\
Cx-P-TPA & CDCA & 636 & 9.34 & 64.77 & 3.85 \\
\hline
\end{tabular}

zation of the devices, prepared as detailed in Supporting Information, are depicted in Table 3 and Fig. 6a.

The efficiency value of the devices performed with $4 H$-pyranylidene donor ring (Cx-2-P) and (Cx-P-TPA) is higher than the one prepared with triphenylamine (Cx-2-TPA) which is due to the higher values of both $J_{s c}$ and field factor $(f f)$.

The cells based on calixarene dyes (Cx-2-TPA), (Cx-2-P) and (Cx-P-TPA) prepared in the described conditions work better without co-adsorbate as it was already reported in a previous paper [14]. The lower efficiency of the devices prepared with CDCA as compared with the ones without the additive is mainly due to the decrease of $J_{s c}$. This is related to the limited adsorption of actives dyes due to the coexistence of CDCA on the electrode.

Trying to optimize the device response and taking into account that there is no evidence of aggregation (Figs. 1 and 2) on devices prepared with the (Cx-2-P) dye for $24 \mathrm{~h}$ of soaking, a new series of devices with longer immersion time periods was prepared to check the photovoltaic values of the ones prepared with calixarene-dyes $(\mathbf{C x}-2-\mathbf{P})$ and (Cx-P-TPA), and (P) for comparision. The photovoltaic parameters are shown in the following Table.

Fig. 5. Canonical forms upon charge polarization of TPA derivatives.
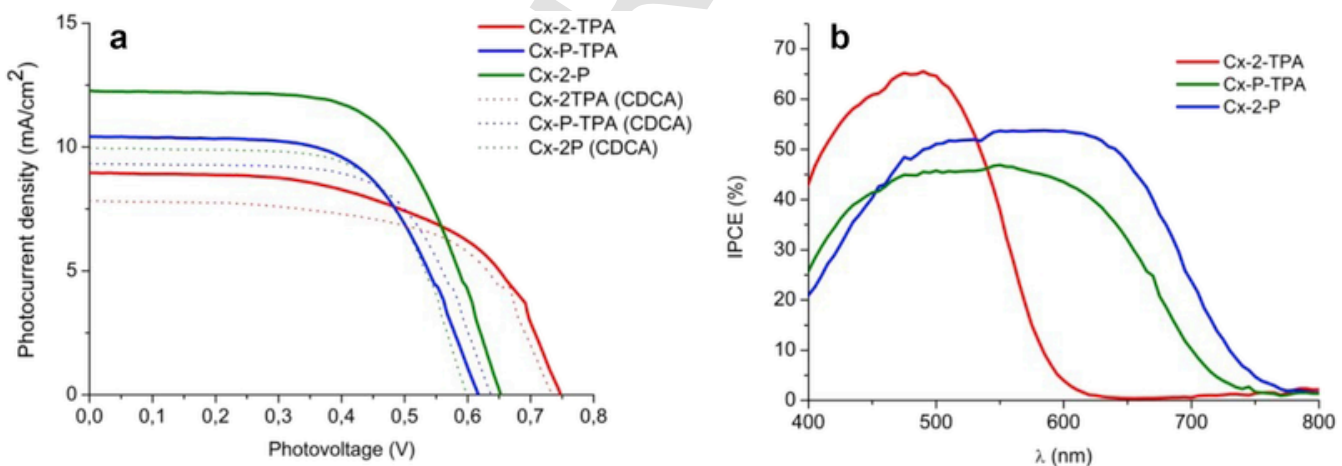

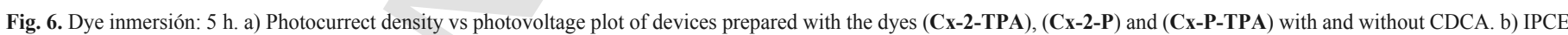
spectra of devices prepared with the dyes (Cx-2-TPA), (Cx-2-P) and (Cx-P-TPA). 
The photocurrent density value of the cells prepared with calixarene dyes (Cx-2-P) and (Cx-P-TPA) is minor with respect to the sole (P) dye which could be explained by the lower amount of dye in the devices prepared with calixarene scaffold. However, the $V_{o c}$ value is higher for cells prepared with calixarene dyes $(\mathbf{C x}-\mathbf{2}-\mathbf{P})$ and (Cx-P-TPA) with respect to the sole (P) dye, which can be attributed to the supression of recombination process on $\mathrm{TiO}_{2}$. This could be due to the calixarene scaffold present in these dyes hindering the access of the electrolyte to the surface of the electrode. Moreover, it should be noticed that the efficiency of the device prepared with the dye (Cx-2-P) is higher than the efficiency obtained for dye (P). (Table 4, Fig. 7a).

The IPCE spectra of Fig. 6b show that the introduction of the dyes derived of 4H-pyranylidene, (Cx-P-TPA) and (Cx-2-P), allows to expand the spectral window significatively with respect to the device prepared with (Cx-2-TPA). Moreover, the IPCE spectra of Fig. 7b shows that the devices prepared with the three dyes exhibit a broad range of photon conversion with respect to the (Cx-2-TPA) dye (Fig. $6 b)$. In particular, the devices prepared with (P) and (Cx-2-P) feature a broad IPCE trace spanning a large spectral window spectrum, around $50 \%$ from 400 to $700 \mathrm{~nm}$, suggesting that electrons are efficiently collected in this region. The IPCE curve of the device constituted by $(\mathbf{P})$ dye is higher than the others which could be related to its $J_{s c}$ value. This value is so high due to both the high amount of dye ad-

Table 4

Photovoltaic performance parameters of DSSC based on adsorbed dyes under AM 1.5 G simulated solar light $\left(100 \mathrm{~mW} \mathrm{~cm}^{-2}\right)$ and $24 \mathrm{~h}$ of electrode immersion on dyes.

\begin{tabular}{llllll}
\hline Dye & Amount $\left(\mathrm{mol} \mathrm{cm}{ }^{-2}\right)$ & $V_{o c}(\mathrm{mV})$ & $J_{s c}\left(\mathrm{~mA} / \mathrm{cm}^{2}\right)$ & $f f(\%)$ & $\eta(\%)$ \\
\hline P & $1.4010^{-7}$ & 562 & 13.60 & 52.67 & 4.03 \\
Cx-2-P & $2.0010^{-8}$ & 596 & 11.80 & 65.93 & 4.64 \\
Cx-P- & $4.4810^{-8}$ & 578 & 10.90 & 62.80 & 3.95 \\
TPA & & & & & \\
\hline
\end{tabular}

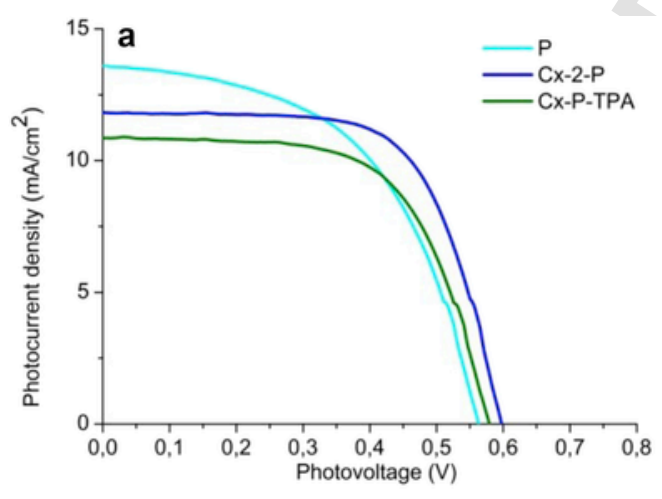

sorbed in the electrode (Table 4 ) and the absorption of $(\mathbf{P})$ dye with respect to the calixarene derivatives.

Electrochemical impedance spectroscopy (EIS) is a very useful tool to study the electron transport kinetics in DSSCs devices. The EIS spectra were performed under forward bias $(-0.65 \mathrm{~V})$ in the dark. Bode phase plots (Fig. 8) were used to estimate the lifetime of electrons $(\tau)$ in the conduction band of $\mathrm{TiO}_{2}$. The lifetimes were calculated following the equation [45] $\tau=1 / 2 \pi f(f$ : frequency at the maximum of the curve in the intermediate frequency region in the Bode plot). The lifetime of electrons are 3, 7, $5 \mathrm{~ms}$ for the dyes (P), (Cx-2-P) and (Cx-P-TPA), respectively [46]. This suggests that the calixarene scaffold reduces the recombination process on the $\mathrm{TiO}_{2}$ surface. This fact supports the above referred increase of the observed open-circuit voltage values on the devices prepared with calixarenes scaffolds.

\section{Conclusions}

Calix[4]arenes disubstituted with two dyes, (TPA) derivative and/ or $4 H$-pyranylidene derivative (P) have been successfully designed and developed for dye-sensitized solar cells (DSSCs).

The UV-vis studies have shown that the molar extinction coefficient of (Cx-2-TPA) and (Cx-2-P) improves with the introduction of the second dye in the same molecule.

Moreover, when $4 H$-pyranylidene derivative dye is included in the same molecule, (Cx-P-TPA), it is observed an almost continuous band along the visible spectrum.

When the devices are prepared on the optimised conditions and despite the fact that the $J_{S C}$ is higher for the devices prepared with $(\mathbf{P})$, the enhance both open-circuit voltage and the field factor $(f f)$ data results in an improved efficiency $(\eta)$ for $(\mathbf{C x}-\mathbf{2}-\mathbf{P})$-sensitized DSSCs.

Therefore, the use of calix[4]arene platform is an interesting strategy which will be used to develop new DSSCs dyes and also the use of more efficient sensitizers would improve the performance of the devices.

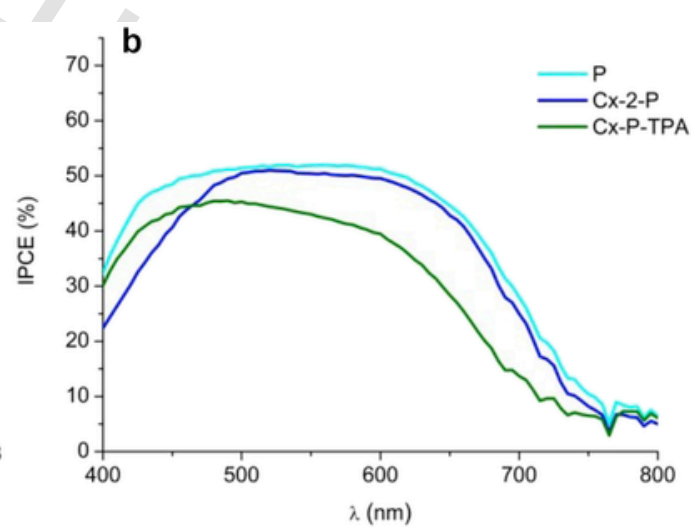

Fig. 7. Dye inmersión: 24 h. a) Photocurrect density vs photovoltage plot of devices prepared with the dyes (P), (Cx-2-P) and (Cx-P-TPA). b) IPCE spectra of devices prepared with the dyes (P), (Cx-2-P) and (Cx-P-TPA). 


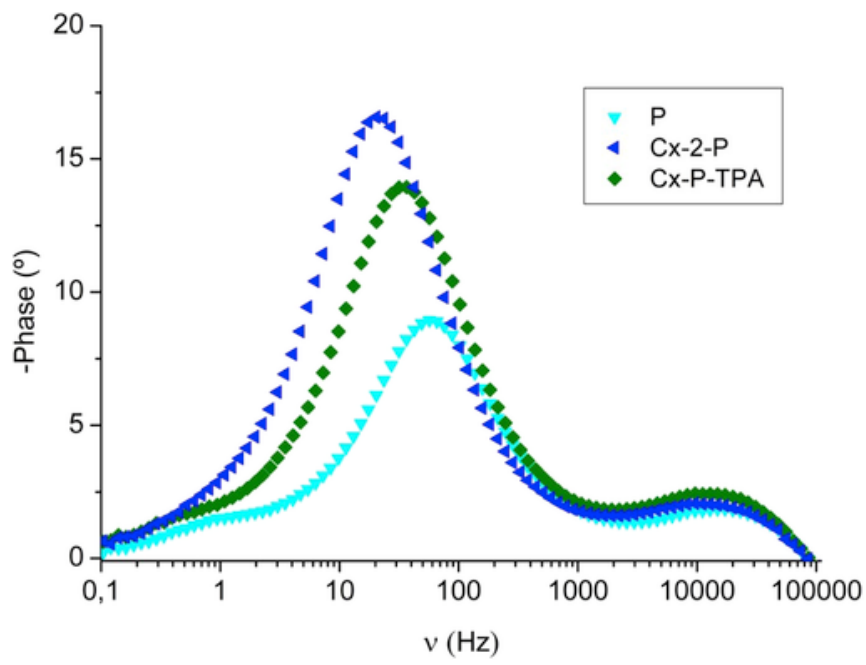

Fig. 8. Bode phase plots of compounds (P), (Cx-2-P) and (Cx-P-TPA)

\section{Experimental}

\subsection{Detailed synthetic procedures}

4.1.1. 5-(2,6-(diphenyl-4H-pyran-4-ylidene)-4-(hydroxymethyl)thiophene-2(2)

To a solution of 4-((tert-butyldimethylsilyloxy)methyl)-5-((2,6-diphenyl-4H-pyran-4-ylidene)methyl)thiophene-2-carbaldehyde (170 $\mathrm{mg}, 0.34 \mathrm{mmol})$ in THF at $0{ }^{\circ} \mathrm{C}$ of temperature under Argon, a solution of tetrabutylammonium fluoride (1 M THF) $(0.68 \mathrm{~mL}, 0.68 \mathrm{mmol})$ was slowly added and was stirred for $90 \mathrm{~min}$. The resulting solution was quenched by the addition of $50 \mathrm{~mL}$ of $\mathrm{NH}_{4} \mathrm{Cl}$ saturated solution (aq). The aqueous phase was extracted with ethyl acetate solution and the organic phase was dried over dry $\mathrm{MgSO}_{4}$ and the solvent was evaporated by reduced pressure. The residue was purified by flash chromatography using dichloromethane/ ethyl acetate from (95:5) to (10:4) to yield (88 mg, 67\%) of a red solid. Molecular weight $(\mathrm{g} / \mathrm{mol}): 386.46$. Melting point $\left({ }^{\circ} \mathrm{C}\right)$ at $760 \mathrm{~mm}$ Hg: 185-189. Elemental analysis found C 74.59, H 4.89, S 8.42\%; molecular formula $\mathrm{C}_{24} \mathrm{H}_{18} \mathrm{O}_{3} \mathrm{~S}$ requires $\mathrm{C} 74.83, \mathrm{H} \mathrm{4.90,} \mathrm{S} 8.45 \%$; IR (nujol, $\mathrm{cm}^{-1}$ ) $1625(\mathrm{C}=\mathrm{C}), 1641(\mathrm{C}=\mathrm{C}), 1742(\mathrm{C}=\mathrm{O}), 3384(\mathrm{O}$ -H). ${ }^{1} \mathrm{H}-\mathrm{NMR}\left(400 \mathrm{MHz}, \mathrm{CD}_{2} \mathrm{Cl}_{2}\right) \delta(\mathrm{ppm}): 4.74(\mathrm{~d}, J=5.6 \mathrm{~Hz}$, $2 \mathrm{H}), 6.25(\mathrm{~s}, 1 \mathrm{H}), 6.67(\mathrm{~d}, J=2.0 \mathrm{~Hz}, 1 \mathrm{H}), 7.32\left(\mathrm{dd}, J_{l}=2.0 \mathrm{~Hz}\right.$, $\left.J_{2}=0.6 \mathrm{~Hz}, 1 \mathrm{H}\right), 7.47-7.53(\mathrm{~m}, 6 \mathrm{H}), 7.72(\mathrm{~s}, 1 \mathrm{H}), 7.81-7.84(\mathrm{~m}, 2 \mathrm{H})$, 7.91-7.94 (m, 2H), $9.80(\mathrm{~s}, 1 \mathrm{H}) .{ }^{13} \mathbf{C}-\mathbf{N M R}\left(100 \mathrm{MHz}, \mathrm{CD}_{2} \mathrm{Cl}_{2}\right) \delta$ (ppm): 59.2, 103.3, 105.1, 109.5, 125.3, 125.9, 129.3, 129.4, 130.3, 130.8, 133.0, 133.7, 137.8, 138.7, 139.0, 148.5, 153.2, 156.0, 182.3. HRMS $\left(\mathrm{ESI}^{+}\right)$. Calculated for $\left[\mathrm{C}_{24} \mathrm{H}_{18} \mathrm{O}_{3} \mathrm{~S}\right]^{+}$: 386.0971. Found: $386.0962[\mathrm{M}]^{+}$.
4.1.2. Synthesis of esters derivatives from alcohol (1) and/or alcohol (2)

To a solution of calixarene diacid (Cx-2) (285 mg, $0.305 \mathrm{mmol})$, 4-dimethylaminopyridine (DMAP) (22 $\mathrm{mg}, 0.184 \mathrm{mmol})$ and 1-ethyl-3-[3-dimethylaminopropyl]carbodiimide hydrochloride (EDC) $(270 \mathrm{mg}, 1.402 \mathrm{mmol})$ were successively added. This mixture was maintained at $0{ }^{\circ} \mathrm{C}$ during $30 \mathrm{~min}$. Alcohol (1) $(0.305 \mathrm{mmol}$, $118 \mathrm{mg}$ ) and alcohol (2) (0.305 mmol, $118 \mathrm{mg})$ were added. The reaction mixture was then stirred at room temperature for 4 days. After concentration under reduced pressure, the residue was purified by flash chromatography hexane/ethyl acetate/ $\mathrm{NEt}_{3}(85 / 15 / 2)$ and then hexane/ethyl acetate/ $\mathrm{NEt}_{3}$ (80/20/2). The three compounds (3), (4) and (5) were obtained and isolated. The characterization of these compounds is shown below.

\section{1.. Compound (3)}

The ester derivative (3) was obtained as an orange solid (161 mg) (yield: $31 \%)$. Molecular weight $(\mathrm{g} / \mathrm{mol})$ : 1668.23 . Melting point $\left({ }^{\circ} \mathrm{C}\right)$ at $760 \mathrm{~mm} \mathrm{Hg:} \mathrm{120-122.} \mathrm{Elemental} \mathrm{analysis} \mathrm{found} \mathrm{C} \mathrm{77.50,} \mathrm{H} \mathrm{7.23,}$ $\mathrm{N} \mathrm{1.64,} \mathrm{S} \mathrm{3.71 \% ;} \mathrm{molecular} \mathrm{formula} \mathrm{C}_{108} \mathrm{H}_{118} \mathrm{~N}_{2} \mathrm{O}_{10} \mathrm{~S}_{2}$ requires $\mathrm{C}$ 77.76, H 7.13, N 1.68, S 3.84\%. IR (KBr) cm ${ }^{-1}: 1738(\mathrm{C}=\mathrm{O}), 1590$ $(\mathrm{C}=\mathrm{C}), 1198(\mathrm{C}-\mathrm{O}) .{ }^{\mathbf{1}} \mathbf{H}-\mathbf{N M R}\left(400 \mathrm{MHz}, \mathrm{CD}_{2} \mathrm{Cl}_{2}\right) \delta(\mathrm{ppm})$ : $0.92(\mathrm{t}, J=7.6 \mathrm{~Hz}, 6 \mathrm{H}), 1.04(\mathrm{~s}, 18 \mathrm{H}), 1.10(\mathrm{~s}, 18 \mathrm{H}), 1.75-1.83(\mathrm{~m}$, $4 \mathrm{H}), 1.94-2.02(\mathrm{~m}, 8 \mathrm{H}), 2.45(\mathrm{t}, J=7.6 \mathrm{~Hz}, 4 \mathrm{H}), 3.08(\mathrm{~d}, J=12.4 \mathrm{~Hz}$, $4 \mathrm{H}), 3.77$ (t, $J=7.6 \mathrm{~Hz}, 4 \mathrm{H}), 3.83$ (t, $J=7.2 \mathrm{~Hz}, 4 \mathrm{H}), 4.34$ (d,

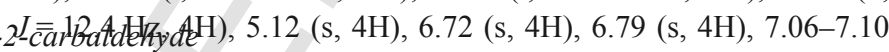
$(\mathrm{m}, 8 \mathrm{H}), 7.13-7.15(\mathrm{~m}, 8 \mathrm{H}), 7.27-7.36(\mathrm{~m}, 12 \mathrm{H}), 7.79(\mathrm{~s}, 2 \mathrm{H}), 9.80$ (s, 2H). ${ }^{13} \mathbf{C}-\mathbf{N M R}\left(100 \mathrm{MHz}, \mathrm{CD}_{2} \mathrm{Cl}_{2}\right) \delta$ (ppm): 10.2, 20.2, 21.7, 23.4, 29.7, 31.0, 31.2, 31.3, 34.2, 59.7, 74.7, 77.0, 121.9, 124.0, 125.0, $125.1,125.3,125.4,129.5,129.9,133.0,133.7,133.9,139.5,144.3$, 144.4, 147.0, 149.2, 153.5, 173.0, 182.6. MS (MALDI $\left.{ }^{+}\right) \mathrm{m} / \mathrm{z}$ : Calculated for $\left[\mathrm{C}_{108} \mathrm{H}_{118} \mathrm{~N}_{2} \mathrm{O}_{10} \mathrm{~S}_{2} \mathrm{Na}\right]:$ 1689.8, Found: $1690.1[\mathrm{M}+\mathrm{Na}]^{+}$.

\section{1.. Compound (4)}

The ester derivative (4) was obtained as red solid (196 mg) (yield: $38 \%)$. Molecular weight $(\mathrm{g} / \mathrm{mol}): 1669.21$. Melting point $\left({ }^{\circ} \mathrm{C}\right)$ at 760 mm Hg: 107-111. Elemental analysis found C 77.71, H 7.06, N 0.84, S 3.84\%; molecular formula $\mathrm{C}_{108} \mathrm{H}_{117} \mathrm{NO}_{11} \mathrm{~S}_{2}$ requires $\mathrm{C}$ 78.00, $\mathrm{H}$ 7.36, N 0.74, S 3.72\%; IR (KBr): $1738(\mathrm{C}=\mathrm{O}), 1663(\mathrm{C}=$ O), $1590(\mathrm{C}=\mathrm{C}) .{ }^{1} \mathbf{H}-\mathbf{N M R}\left(400 \mathrm{MHz}, \mathrm{CD}_{2} \mathrm{Cl}_{2}\right) \delta(\mathrm{ppm}): 1.00(\mathrm{t}$, $J=7.2 \mathrm{~Hz}, 6 \mathrm{H}), 1.05(\mathrm{~s}, 18 \mathrm{H}), 1.07(\mathrm{~s}, 18 \mathrm{H}), 1.73-1.83(\mathrm{~m}, 4 \mathrm{H})$, 1.93-2.02 (m, 8H), 2.42-2.50 (m, 4H), $3.08(\mathrm{~d}, J=3.2 \mathrm{~Hz}, 2 \mathrm{H})$, $3.12(\mathrm{~d}, J=3.2 \mathrm{~Hz}, 2 \mathrm{H}), 3.76(\mathrm{t}, J=7.8 \mathrm{~Hz}, 4 \mathrm{H}), 3.84(\mathrm{~m}, 4 \mathrm{H}), 4.33$ $(\mathrm{d}, J=3.5 \mathrm{~Hz}, 2 \mathrm{H}), 4.36(\mathrm{~d}, J=3.5 \mathrm{~Hz}, 2 \mathrm{H}), 5.11(\mathrm{~s}, 2 \mathrm{H}), 5.16$ (s, $2 \mathrm{H}), 5.33(\mathrm{~s}, 1 \mathrm{H}) 6.32(\mathrm{~s}, 1 \mathrm{H}), 6.64(\mathrm{~d}, J=1.9 \mathrm{~Hz}, 1 \mathrm{H}), 6.76(\mathrm{~s}$, $4 \mathrm{H})$, 6.78 
4H), 7.03-7.15 (m, 8H), 7.27-7.32 (m, 4H), 7.33-7.36 (m, 2H), 7.46-7.54 (m, 6H), $7.69(\mathrm{~s}, 1 \mathrm{H}), 7.79(\mathrm{~s}, 1 \mathrm{H}), 7.80-7.82(\mathrm{~m}, 2 \mathrm{H})$, 7.89-7.91 (m, 2H), 9.77 (s, 1H), $9.78(\mathrm{~s}, 1 \mathrm{H}) .{ }^{13} \mathbf{C}-\mathbf{N M R}(100 \mathrm{MHz}$, $\left.\mathrm{CD}_{2} \mathrm{Cl}_{2}\right) \delta$ (ppm): 10.7, 22.3, 24.0, 30.3, 31.5, 31.8, 31.8, 34.2, 34.7, $34.7,59.8,60.2,75.2,75.277 .5,103.3,104.7,109.5,122.4,124.6$, $125.4,125.6,125.9,126.0,129.4,129.5,130.0,130.4,130.9,134.3$, 134.4, 139.5, 140.0, 144.9, 144.9, 147.5, 154.0, 154.2, 174.7, 183.13. MS $\left(\mathrm{MALDI}^{+}\right) \mathrm{m} / \mathrm{z}$ : Calculated for $\left[\mathrm{C}_{108} \mathrm{H}_{117} \mathrm{NO}_{11} \mathrm{~S}_{2} \mathrm{Na}\right]$ : 1690.8 . Found: $1690.9[\mathrm{M}+\mathrm{Na}]^{+}$.

\section{1.. Compound (5)}

The ester derivative (5) was obtained as a red solid (140 mg) (yield: $27 \%$ ). Molecular weight $(\mathrm{g} / \mathrm{mol}): 1668.23$. Melting point $\left({ }^{\circ} \mathrm{C}\right)$ at $760 \mathrm{~mm} \mathrm{Hg:} \mathrm{94-97} \mathrm{(d).} \mathrm{Elemental} \mathrm{analysis} \mathrm{found} \mathrm{C} \mathrm{77.66,} \mathrm{H} \mathrm{7.27,}$ $\mathrm{N}$ 11.78, S 3.66\%; molecular formula $\mathrm{C}_{108} \mathrm{H}_{116} \mathrm{O}_{12} \mathrm{~S}_{2}$ requires $\mathrm{C} 77.96$, H 7.30, N 11.82, S 3.65\%; IR (KBr, cm $\left.{ }^{-1}\right) 1737(\mathrm{C}=\mathrm{O}), 1657(\mathrm{C}=$ O). ${ }^{1} \mathbf{H}-\mathbf{N M R}\left(400 \mathrm{MHz}, \mathrm{CD}_{2} \mathrm{Cl}_{2}\right) \delta$ (ppm): $0.98(\mathrm{t}, J=7,5 \mathrm{~Hz}, 6 \mathrm{H})$, $1.02(\mathrm{~s}, 18 \mathrm{H}), 1.11(\mathrm{~s}, 18 \mathrm{H}), 1.76-1.83(\mathrm{~m}, 4 \mathrm{H}), 1.92-2.07(\mathrm{~m}, 8 \mathrm{H})$, 2.49, (t, $J=7.5 \mathrm{~Hz}, 4 \mathrm{H}), 3.08(\mathrm{~d}, J=12.5 \mathrm{~Hz}, 4 \mathrm{H}), 3.74(\mathrm{t}, J=7.7 \mathrm{~Hz}$, $4 \mathrm{H}), 3.88(\mathrm{t}, J=7.7 \mathrm{~Hz}, 4 \mathrm{H}), 4.36(\mathrm{~d}, J=12.5 \mathrm{~Hz}, 4 \mathrm{H}), 5.16(\mathrm{~s}, 4 \mathrm{H})$, $6.16(\mathrm{~s}, 2 \mathrm{H}), 6.58(\mathrm{~d}, J=1.9 \mathrm{~Hz}, 2 \mathrm{H}), 6.72(\mathrm{~s}, 4 \mathrm{H}), 6.83(\mathrm{~s}, 4 \mathrm{H}), 7.21$ (d, $J=1.9 \mathrm{~Hz}, 2 \mathrm{H}), 7.42-7.48(\mathrm{~m}, 12 \mathrm{H}), 7.66(\mathrm{~s}, 2 \mathrm{H}), 7.73-7.76(\mathrm{~m}$, 4H) 7.80-7.83 (m, 4H), $9.72(\mathrm{~s}, 2 \mathrm{H}) .{ }^{13} \mathbf{C}-\mathbf{N M R}\left(100 \mathrm{MHz}, \mathrm{CD}_{2} \mathrm{Cl}_{2}\right) \delta$ (ppm): 10.8, 22.2, 24.0, 30.3, 31.5, 31.7, 31.8, 34.2, 34.3, 34.8, 59.8, $75.2,77.6,103.2,104.7,109.5,125.2,125.5,125.6,125.9,129.3$, $129.4,130.3,130.8,134.0,134.7,139.4,144.8,145.0,149.8,154.3$, 173.7, 182.2. MS $\left(\mathrm{MALDI}^{+}\right) \mathrm{m} / \mathrm{z}$ : Calculated for $\left[\mathrm{C}_{108} \mathrm{H}_{116} \mathrm{O}_{12} \mathrm{~S}_{2} \mathrm{Na}\right]$ : 1691.8. Found: $1691.9[\mathrm{M}+\mathrm{Na}]^{+}$.

\subsection{Compound (Cx-2-TPA)}

To a solution of compound (3) (140 mg, $0.113 \mathrm{mmol})$ and 2-cyanoacetic acid $(76.2 \mathrm{mg}, 0.893 \mathrm{mmol})$ in chloroform $(12 \mathrm{~mL})$ piperidine $(216.1 \mu \mathrm{L} ; 2.229 \mathrm{mmol})$ was added. The mixture was heated at $65^{\circ} \mathrm{C}$ of temperature for 4 days under argon atmosphere and prevented for light, then it was cooled down to room temperature. After concentration under reduced pressure, the resulting solid was solved with $\mathrm{CH}_{2} \mathrm{Cl}_{2}$, acidified with $\mathrm{HCl} 0.1 \mathrm{M}$, and was washed with water. The solution was dried and the solvent was removed under reduced pressure. The resulting solid was filtered and washed with cold $\mathrm{MeOH}$ and a red solid (55 mg) was obtained (Yield: $30 \%$ ).

Molecular weight (g/mol): 1800.83 . IR $(\mathrm{KBr}) \mathrm{cm}^{-1}: 2218(\mathrm{C} \Xi \mathrm{N})$, $1736(\mathrm{C}=\mathrm{O}), 1585(\mathrm{C}=\mathrm{C}), 1197(\mathrm{C}-\mathrm{O})$. Melting point $\left({ }^{\circ} \mathrm{C}\right)$ at $760 \mathrm{~mm} \mathrm{Hg:} 160-162 .{ }^{1} \mathrm{H}-\mathrm{NMR}\left(400 \mathrm{MHz}, \mathrm{CD}_{2} \mathrm{Cl}_{2}\right) \delta$ (ppm): 0.92-0.97 (m, 6H), 0.97 (s, 18H), $1.13(\mathrm{~s}, 18 \mathrm{H}), 1.70-1.75(\mathrm{~m}, 4 \mathrm{H})$, 1.89-1.97 (m, 4H), 2.03-2.08 (m, 4H), 2.42-2.51 (m, 4H), 3.07 (d, $J=12 \mathrm{~Hz}$,
3.67-3.73 (m, 4H), 3.83-3.91 (m, 4H), 4.33 (d, $J=12.4 \mathrm{~Hz}, 4 \mathrm{H}), 5.06$ (s, 4H), $6.66(\mathrm{~s}, 4 \mathrm{H}), 6.87(\mathrm{~s}, 4 \mathrm{H}), 6.98-7.01(\mathrm{~m}, 4 \mathrm{H}), 7.07-7.09(\mathrm{~m}$, 12H), 7.24-7.30 (m, 12H), 7.75 (s, 2H), 8.27 (s, 2H). ${ }^{13}$ C- NMR $\left(100 \mathrm{MHz}, \mathrm{CD}_{2} \mathrm{Cl}_{2}\right) \delta(\mathrm{ppm}): 10.4,21.6,23.5,29.8,31.0,31.2,31.4$, $33.7,34.2,60.0,74.7,77.2,121.6,124.1,124.9,125.2,125.5,129.6$, 129.9, 133.3, 134.5, 144.6, 146.9, 149.3, 153.4. M.S. $\left(\mathrm{MALDI}^{+}\right) \mathrm{m} / \mathrm{z}$ : Calculated $\left[\mathrm{C}_{114} \mathrm{H}_{120} \mathrm{~N}_{4} \mathrm{O}_{12} \mathrm{~S}_{2} \mathrm{Na}\right]$ : 1823.8. Found: 1823.9 .

\section{1.. Compound (CX-P-TPA)}

To a solution of compound (4) (195 $\mathrm{mg}, 0.117 \mathrm{mmol})$ and 2-cyanoacetic acid $(50 \mathrm{mg}, 0.585 \mathrm{mmol})$ in chloroform $(10 \mathrm{~mL})$, piperidine $(0.182 \mathrm{~mL}, 1.774 \mathrm{mmol})$ was added. The mixture was heated at reflux for 4 days under argon atmosphere and prevented for light, and then it was cooled down to room temperature. After concentration under reduced pressure, the resulting solid was solved with $\mathrm{CH}_{2} \mathrm{Cl}_{2}$, acidified with $\mathrm{HCl} 0.1 \mathrm{M}$, and washed with water. The solution was dried and the solvent was removed under reduced pressure. The resulting solid was filtered and washed with cold $\mathrm{MeOH}$. Tetrahydrofurane was added and the solution was acidified with acetic acid. A dark solid was obtained $(90 \mathrm{mg}, 43 \%)$. Molecular weight $(\mathrm{g} / \mathrm{mol})$ : 1803.31. Melting point $\left({ }^{\circ} \mathrm{C}\right)$ at $\mathbf{7 6 0} \mathbf{~ m m ~} \mathbf{~ H g}: 151-153$. Elemental analysis found $\mathrm{C} 75.93, \mathrm{H} 6.65, \mathrm{~N} 2.33, \mathrm{~S} 3.56 \%$; molecular formula $\mathrm{C}_{114} \mathrm{H}_{119} \mathrm{~N}_{3} \mathrm{O}_{13} \mathrm{~S}_{2}$ requires C 75.75, H 6.34, N 2.26, S 3.37\%; IR (KBr, $\left.\mathrm{cm}^{-1}\right) 3478(\mathrm{C}=\mathrm{O}), 2214(\mathrm{CN}), 1735(\mathrm{C}=\mathrm{O}), 1646(\mathrm{C}=\mathrm{O}), 1562$ $(\mathrm{C}=\mathrm{C}) .{ }^{1}$ H-NMR $\left(400 \mathrm{MHz}, \mathrm{THF}_{-} \mathrm{d}^{8}\right) \delta(\mathrm{ppm}): 0.95-0.99(\mathrm{~m}, 6 \mathrm{H})$, $1.02-1.12(\mathrm{~m}, 36 \mathrm{H}), 1.79-1.85(\mathrm{~m}, 4 \mathrm{H}), 1.95-2.04(\mathrm{~m}, 8 \mathrm{H}), 2.42-2.49$ (m, 4H), 3.04-3.10 (m, 4H), 3.75-3.85 (m, 8H), 4.36-4.43 (m, 4H), 5.03-5.19 (m, 5H), 5,81 (s, 1H), 6.70-6.84 (m, 10H), 7.01-7.10 (m, $10 \mathrm{H}), 7.15-7.28(\mathrm{~m}, 6 \mathrm{H}), 7.35-7.48(\mathrm{~m}, 6 \mathrm{H}), 7.71-8.04(\mathrm{~m}, 5 \mathrm{H})$, 8.27 (bs, 2H). ${ }^{13}$ C-NMR (100 MHz, THF-d $\left.{ }^{8}\right) \delta$ (ppm): 10.9, 22.7, 24.3, 30.8, 31.9, 32.0, 34.5, 34.6, 34.8, 59.7, 60.6, 75.7, 75.7 77.9, $103.9,105.8,113.4,123.0,123.5,124.4,125.8,125.9,126.0,126.0$, $126.2,126.2,126.2,129.7,129.7,129.9,130.3,130.4,130.4,130.7$, $130.8,134.5,134.6,135.0,138.2,144.9,144.9,148.1,148.5,154.6$, 154.6, 154.7, 154.8, 173.3, 173.3. MS $\left(\mathrm{MALDI}^{+}\right) \mathrm{m} / \mathrm{z}$ : Calculated for $\left[\mathrm{C}_{114} \mathrm{H}_{119} \mathrm{~N}_{3} \mathrm{O}_{13} \mathrm{~S}_{2}\right]: 1801.8$. Found: $1801.5[\mathrm{M}]^{+}$.

\subsection{Compound (Cx-2-P)}

To a solution of compound (5) $(130 \mathrm{mg}, 0.078 \mathrm{mmol})$ and 2-cyanoacetic acid $(33 \mathrm{mg}, 0,390 \mathrm{mmol})$ in chloroform $(10 \mathrm{~mL})$, piperidine $(0.118 \mathrm{~mL}, 1.186 \mathrm{mmol})$ was added. The mixture was heated at $55^{\circ} \mathrm{C}$ of temperature for 5 days under argon atmosphere and prevented for light, and then it was cooled down to room temperature. After concentration under reduced pressure, the resulting solid was solved with $\mathrm{CH}_{2} \mathrm{Cl}_{2}$, acidified with $\mathrm{HCl} 1 \mathrm{M}$, and was washed with water. The solution was dried and the solvent was 
removed under reduced pressure. The resulting solid was filtered and washed with cold $\mathrm{MeOH}$ and a red solid was obtained (76 mg, 54\%). Molecular weight $(\mathrm{g} / \mathrm{mol}): 1804.3$. Melting point $\left({ }^{\circ} \mathrm{C}\right)$ at $760 \mathbf{~ m m}$ Hg: 170-174. Elemental analysis found C 75.89, H 6.59, N 1.55, S $3.55 \%$; molecular formula $\mathrm{C}_{114} \mathrm{H}_{118} \mathrm{~N}_{2} \mathrm{O}_{14} \mathrm{~S}_{2}$ requires C 75.63, H 6.39, $\left.\mathrm{N} \mathrm{1.43,} \mathrm{S} \mathrm{3.32 \% ;} \mathrm{IR} \mathrm{(KBr,} \mathrm{cm}{ }^{-1}\right) 3442(\mathrm{O}-\mathrm{H}), 2194(\mathrm{CN}), 1736$ $(\mathrm{C}=\mathrm{O}), 1650(\mathrm{C}=\mathrm{O}), 1577(\mathrm{C}=\mathrm{C}), 1546(\mathrm{C}=\mathrm{C}) .{ }^{1} \mathbf{H}-\mathbf{N M R}$ (400 MHz, THF-d $\left.{ }^{8}\right) \delta(\mathrm{ppm}): 0.94-0.97(\mathrm{~m}, 6 \mathrm{H}), 1.01$ (s, 18H), 1,10 (s, 18H), 1.75-1.82 (m, 4H), 1.96-2.05 (m, 8H), $2.52(\mathrm{t}, J=7.7 \mathrm{~Hz}$, $4 \mathrm{H}), 3.10(\mathrm{~d}, J=12.4 \mathrm{~Hz}, 4 \mathrm{H}), 3.76$ (t, $J=7.5 \mathrm{~Hz}, 4 \mathrm{H}), 3.92$ (t, $J=7.5 \mathrm{~Hz}, 4 \mathrm{H}), 4.42(\mathrm{~d}, J=12.4 \mathrm{~Hz}, 4 \mathrm{H}), 5.18(\mathrm{~s}, 4 \mathrm{H}), 6.28(\mathrm{~s}, 2 \mathrm{H})$, $6.71(\mathrm{~s}, 4 \mathrm{H}), 6.78-6.82(\mathrm{~m}, 4 \mathrm{H}), 6.89(\mathrm{~s}, 4 \mathrm{H}), 7.39-7.45(\mathrm{~m}, 12 \mathrm{H})$, 7.70 (s, 2H), 7.81-7.83 (m. 4H), 7.85-7.87 (m, 4H), 8.19 (s, 2H). ${ }^{13}$ C-NMR (100 MHz, THF-d $\left.{ }^{8}\right) \delta$ (ppm): 11.2, 22.7, 24.0, 24.5, 31.0, 32.0, 32.1, 32.2, 34.6, 34.7, 34.9, 59.9, 75.8, 78.1, 97.0, 104.0, 105.8, $110.3,125.8,125.8,126.1,126.3,129.7,129.9,131.8,133.3,133.6$, 134.4, 134.5, 134.7, 135.4, 144.9, 145.8, 150.2, 154.0, 156.8, 164.8, 173.5. MS Calculated for $\left[\mathrm{C}_{114} \mathrm{H}_{118} \mathrm{~N}_{2} \mathrm{O}_{14} \mathrm{~S}_{2} \mathrm{Na}\right]$ : 1826.8. Found: $1826.2[\mathrm{M}+\mathrm{Na}]^{+}$.

\section{Acknowledgements}

We gratefully acknowledge the financial support from the Spanish Ministry of Science and Innovation, MICINN-FEDER (Project CTQ 2014-52331-R) and the Gobierno de Aragón-Fondo Social Europeo (E39, E07). We also acknowledge Gemma Cepriá from Departamento de Química Analítica (Univ. Zaragoza) for the Impedance Spectroscopy support. Moreover, the "ICMA-Pi2 program" is gratefully acknowledged for the fellowship (EC).

\section{Appendix A. Supplementary data}

Supplementary data related to this article can be found at http://dx. doi.org/10.1016/j.dyepig.2016.08.067.

\section{References}

[1] S.M. Feldt, E.A. Gibson, E. Gabrielsson, L. Sun, G. Boschloo, A. Hagfeldt, Design of organic dyes and cobalt polypyridine redox mediators for high-efficiency dye-sensitized solar cells, J Am Chem Soc (132) (2010) 16714-16724, http://dx.doi.org/10.1021/ja1088869. Epub 2010 Nov 3.

[2] H. Qin, S. Wenger, M. Xu, F. Gao, X. Jing, P. Wang, et al., An organic sensitizer with a fused dithienothiophene unit for efficient and stable dye-sensitized solar cells, J Am Chem Soc 130 (2008) 9202-9203, http://dx.doi.org/10.1021/ ja8024438.

[3] J.N. Clifford, M. Planells, E. Palomares, Advances in high efficiency dye sensitized solar cells based on $\mathrm{Ru}(\mathrm{II})$ free sensitizers and a liquid redox electrolyte, J Mater Chem 22 (2012) 24195-24201, http://dx.doi.org/10.1039/ C2JM34289H.
[4] N. Hirata, J.J. Lagref, E.J. Palomares, J.R. Durrant, M.K. Nazeeruddin, M. Gratzel, et al., Supramolecular control of charge-transfer dynamics on dye-sensitized nanocrystalline $\mathrm{TiO}_{2}$ films, Chem Eur J 10 (2004) 595-602, http://dx. doi.org/10.1002/chem.200305408.

[5] J.N. Clifford, E. Palomares, M.K. Nazeeruddin, M. Gratzel, J. Nelson, X. Li, et al., Molecular control of recombination dynamics in dye-sensitized nanocrystalline $\mathrm{TiO}_{2}$ films: free energy vs distance dependence, J Am Chem Soc 126 (2004) 5225-5233, http://dx.doi.org/10.1021/ja039924n.

[6] J.-H. Yum, P. Chen, M. Gratzel, M.K. Nazeeruddin, Recent“ developments in solid-state dye-sensitized solar cells, ChemSusChem 1 (2008) 699-707, http:// dx.doi.org/10.1002/cssc. 200800084 .

[7] A. Kay, M. Gratzel, Artificial photosynthesis. 1. Photo-sensitization of titania solar cells with chlorophyll derivatives and related natural porphyrins, J Phys Chem 97 (1993) 6272-6277, http://dx.doi.org/10.1021/j100125a029.

[8] K. Hara, Y. Dan-oh, C. Kasada, Y. Ohga, A. Shinpo, S. Suga, et al., Effect of Additives on the photovoltaic performance of coumarin-dye-sensitized nanocrystalline $\mathrm{TiO}_{2}$ solar cells, Langmuir 20 (2004) 4205-4210, http://dx.doi. org/10.1021/la0357615.

[9] J.-H. Yum, T.W. Holcombe, Y. Kim, K. Rakstys, T. Moehl, J. Teuscher, et al., Blue-coloured highly efficient dye-sensitized solar cells by implementing the diketopyrrolopyrrole chromophore, Sci Rep 2446 (2013) http://dx.doi.org/10. 1038/srep02446.

[10] M. Zhang, Y. Wang, M. Xu, W. Ma, R. Li, P. Wang, Design of high-efficiency organic dyes for titania solar cells based on the chromophoric core of cyclopentadithiophene-benzothiadiazole, Energy Environ Sci 6 (2013) 2944-2949, http://dx.doi.org/10.1039/C3EE42331J.

[11] M. Liang, J. Chen, Arylamine organic dyes for dye-sensitized solar cells, Chem Soc Rev 42 (2013) 3453-3488, http://dx.doi.org/10.1039/C3CS35372A.

[12] G.D. Sharma, K.R. Patel, M.S. Roy, R. Misra, Characterization of two new $(\mathrm{A}-\pi)_{2}-\mathrm{D}-\mathrm{A}$ type dyes with different central D unit and their application for dye sensitized solar cells, Org Electr 15 (2014) 1780-1790, http://dx.doi.org/ 10.1016/j.orgel.2014.05.002.

[13] R. Andreu, L. Carrasquer, S. Franco, J. Garín, J. Orduna, N. Martínez de Baroja, et al., 4H-Pyran-4-ylidenes: strong proaromatic donors for organic nonlinear optical chromophores, J Org Chem 74 (2009) 6647-6657, http://dx. doi.org/10.1021/jo901142f.

[14] J.M. Andrés-Castán, S. Franco, B. Villacampa, J. Orduna, R. Pérez-Tejada, New efficient tert-butyldiphenyl-4H-pyranylidene sensitizers for DSSCs, RSC Adv 5 (2015) 106706-106709, http://dx.doi.org/10.1039/C5RA23339A.

[15] R. Pérez-Tejada, N. Martínez de Baroja, S. Franco, L. Pellejà, J. Orduna, R. Andreu, et al., Organic sensitizers bearing a trialkylsilyl ether group for liquid dye sensitized solar cells, Dyes Pigments 123 (2015) 293-303, http://dx.doi. org/10.1016/j.dyepig.2015.07.026.

[16] R. Pérez-Tejada, L. Pellejà, E. Palomares, S. Franco, J. Orduna, J. Garín, et al., Novel $4 \mathrm{H}-$ 
pyranylidene organic dyes for dye-sensitized solar cells: effect of different heteroaromatic rings on the photovoltaic properties, Org Electr 2014 (15) (2014) 3237-3250, http://dx.doi.org/10.1016/j.orgel.2014.09.003.

[17] S. Franco, J. Garin, N.M. De Baroja, R. Perez-Tejada, J. Orduna, Y.H. Yu, et al., New d-pi-a-conjugated organic sensitizers based on 4H-Pyran-4-ylidene donors for highly efficient dye-sensitized solar cells, Org Lett 14 (2012) 752-755, http://dx.doi.org/10.1021/ol203298r.

[18] A. Bolaga, J.-I. Nishida, K. Hara, Y. Yamashita, Enhanced performance of dye-sensitized solar cells with novel 2,6-diphenyl-4H-pyranylidene dyes, Org Electr 13 (2012) 425-431, http://dx.doi.org/10.1016/j.orgel.2011.11.020.

[19] M. Paramasivarn, R.K. Chitumalla, S.P. Singh, A. Islam, L. Han, V.J. Rao, et al., Tuning the photovoltaic performance of benzocarbazole-based sensitizers for dye-sensitized solar cells: a joint experimental and theoretical study of the influence of pi-spacers, J Phys Chem C 119 (2015) 17053-17064, http:// dx.doi.org/10.1021/acs.jpcc.5b04629.

[20] S. Zhu, Z. An, Xi Chen, P. Chen, Q. Liu, Cyclic thiourea functionalized dyes with binary pi-linkers: influence of different pi-conjugation segments on the performance of dye-sensitized solar cells, Dyes Pigments 116 (2015) 146-154, http://dx.doi.org/10.1016/j.dyepig.2011.09.003.

[21] W. Lee, J. Choi, J.W. Namgoong, S.H. Kim, K.C. Sun, S.H. Jeong, et al., The effect of five-membered heterocyclic bridges and ethoxyphenyl substitution on the performance of phenoxazine-based dye-sensitized solar cells, Dyes Pigments 104 (2014) 185-193, http://dx.doi.org/10.1016/j.dyepig.2011.09.003.

[22] H. Jia, X. Ju, M. Zhang, Z. Ju, H. Zheng, Effects of heterocycles containing different atoms as pi-bridges on the performance of dye-sensitized solar cells, Phys Chem Chem Phys 17 (2015) 16334-16340, http://dx.doi.org/10.1039/ C5CP02194D.

[23] P. Gao, H.N. Tsao, C. Yi, M. Grätzel, M.K. Nazeeruddin, Extended $\pi$-bridge in organic dye-sensitized solar cells: the longer, the better?, Adv Energy Mater 4 (2004) 1301485-1301491, http://dx.doi.org/10.1002/aenm. 201301485.

[24] J. Wiiberg, T. Marinado, D.P. Hagberg, L. Sun, A. Hagfeldt, B. Albinsson, Effect of anchoring group on electron injection and recombination dynamics in organic dye-sensitized solar cells, J Phys Chem C 113 (2009) 3881-3886, http: //dx.doi.org/10.1021/jp8101139.

[25] D. Cao, J. Peng, Y. Hong, X. Fang, L. Wang, H. Meier, Enhanced performance of the dye-sensitized solar cells with phenothiazine-based dyes containing double D-A branches, Org Lett 13 (2011) 1610-1613, http://dx.doi.org/10.1021/ ol2000167.

[26] R. Grisorio, L. De Marco, G. Allegretta, R. Giannuzzi, G.P. Suranna, M. Manca, et al., Anchoring stability and photovoltaic properties of new $\mathrm{D}(-\mathrm{pi}-\mathrm{A})(2)$ dyes for dye-sensitized solar cell applications, Dyes Pigments 98 (2013) 221-231, http://dx.doi.org/10.1016/j.dyepig.2013.02.012.

[27] Reenu Sirohi, Dong Hee Kim, Soo-Chang Yu, et al., Novel di-anchoring dye for DSSC by bridging of two mono anchoring dye molecules: a conformational approach to reduce aggregation, Dyes Pigments 92 (2012) 1132-1137, http://dx.doi.org/10.1016/j.dyepig.2011.09.003.

[28] K. Hara, Y. Dan-oh, Kasada Ch, Y. Ohga, A. Shinpo, S. Suga, et al., Effect of additives on the photovoltaic performance of coumarin-dye-sensitized nanocrystalline $\mathrm{TiO}_{2}$ solar cells, Langmuir 20 (2004) 4205-4210, http://dx.doi. org/10.1021/la0357615.

[29] X. Ren, Q. Feng, G. Zhou, C.-H. Huang, Z.S. Wang, Effect of cations in coadsorbate on charge recombination and conduction band edge movement in dye-sensitized solar cells, J Phys Chem C 114 (2010) 7190-7195, http://dx.doi. org/10.1021/jp911630z.

[30] Z. Wang, M. Liang, H. Wang, P. Wang, F. Cheng, Z. Sun, et al., Joint electrical, photophysical, and photovoltaic studies on truxene dye-sensitized solar cells: impact of arylamine electron donors, ChemSusChem 7 (2014) 795-803, http://dx.doi.org/10.1002/cssc.201301155.

[31] H. Choi, C. Baik, S.O. Kang, J. Ko, M.S. Kang, K. Nazeeruddin Md, et al., Highly efficient and thermally stable organic sensitizers for solvent-free dye-sensitized solar cells, Angew Chem Int Ed 47 (2008) 327-330, http://dx. doi.org/10.1002/anie.200703852.

[32] W.-I. Hung, Y.-Y. Liao, T.-H. Lee, Y.-C. Ting, J.-S. Ni, W.-S. Kao, et al., Eugenic metal-free sensitizers with double anchors for high performance dye-sensitized solar cells, Chem Comm 51 (2015) 2152-2155, http://dx.doi.org/10. 1039/C4CC09294E.

[33] R. Andreu, S. Franco, J. Garin, J. Romero, B. Villacampa, M.J. Blesa, et al., ChemPhysChem 13 (2012) 3204-3209, http://dx.doi.org/10.1002/cphc. 201200203.

[34] M. Castillo-Vallés, J.M. Andrés-Castán, J. Garín, J. Orduna, B. Villacampa, S. Franco, et al., Dye-sensitized-solar-cells based on calix[4]arene scaffolds, RSC Adv 5 (2015) 90667-90670, http://dx.doi.org/10.1039/c5ra15184h.

[35] K. Iwamoto, S. Shinkai, Synthesis and ion selectivity of all conformational isomers of tetrakis[(ethoxycarbonyl)methoxy]calix[4]arene, J Org Chem 57 (1992) 7066-7073, http://dx.doi.org/10.1021/jo00052a016.

[36] K. Iwamoto, K. Araki, S. Shinkai, Conformations and structures of tetra-O-alkyl-p-tert-butylcalix[4]arenes. How is the conformation of calix[4]arenes immobilized?, J Org Chem 56 (1991) 4955-4962, http://dx.doi. org/10.1021/jo00016a027.

[37] B.S. Creaven, D.F. Donlon, J. McGinley, Coordination chemistry of calix[4]arene derivatives with lower rim functionalisation and their applications, Coord Chem Rev 253 (2009) 893-962, http://dx.doi.org/10.1016/j.ccr. 2008.06.008

[38] L.L. Tan, J.M. Liu, S.Y. Li, L.M. Xiao, D.B. Kuang, C.Y. Su, Dye-sensitized solar cells with improved performance using cone-Calix[4]arene based dyes, ChemSusChem 8 (2015) 280-287, http://dx.doi.org/10.1002/cssc.201402401.

[39] M.J. Blesa, B. Zhao, M. Allain, F. Le Derf, M. Sallé, Bis(calixcrown)tetrathiafulvalene receptors, 
Chem Eur J 1906-14 (12) (2006) http://dx.doi.org/10.1002/chem.200500878.

[40] Y. Rudzevich, K. Fischer, M. Schmidt, V. Böhmer, Fourfold tetraurea calix[4]arenes - potential cores for the formation of self-assembled dendrimers, Org Biomol Chem 3 (2005) 3916-3925, http://dx.doi.org/10.1039/ B509948J.

[41] I. Bitter, A. Grün, G. Téth, B. Balázs, G. Horváth, L. Töke, Tetrahedron 54 (1998) 3857-3870, http://dx.doi.org/10.1016/S0040-4020(98)00112-4.

[42] Y. Rudzevich, Synthesis and characterization of tetraurea derivatives of calix[4]arenes, $\mathrm{PhD}$ thesis 2005 .

[43] F. Nüesch, M. Grätzel, H-aggregation and correlated absorption and emission of a merocyanine dye in solution, at the surface and in the solid state. A link between crystal structure and photophysical properties, Chem Phys 193 (1995) 1-17, http://dx.doi.org/10.1016/ 0301-0104(94)00405-Y.

[44] G. Zhou, N. Pscirer, J.C. Schoneboom, F. Eickemeyer, M. Baumgarten, K. Mullen, Ladder-type pentaphenylene dyes for dye-sensitized solar cells, Chem Mater 20 (2008) 1808-1815, http://dx.doi.org/10.1021/cm703459p.

[45] J. Bisquert, F. Fabregat-Santiago, I. Mora-Seró, G. García-Belmonte, S. Giménez, Electron lifetime in dye-sensitized solar cells: theory and interpretation of measurements, J Phys Chem C 113 (2009) 17278-17290, http://dx.doi. org/10.1021/jp9037649

[46] F. Guo, J. He, S. Qu, J. Li, Q. Zhang, W. Wu, et al., Structure-property relationship of different electron donors: new organic sensitizers based on bithiazole moiety for high efficiency dye-sensitized solar cells, RSC Adv 3 (2013) 15900-15908, http://dx.doi.org/10.1039/C3RA00181D. 